\title{
辺縁性歯周炎の急性症状に対する塩酸ミノサイクリン含有 局所投与薬剤の臨床的および細菌学的評価
}

\begin{tabular}{|c|c|c|c|}
\hline 野口俊英 & 浅井昭 博 & 小出雅則 & 酒井秀人 \\
\hline 森田佳宏 & 厚 & 高田哲夫 & 村 瀬 元 康 \\
\hline 上田信男 & 黒 柳 隆 穂 & 西山左枝子 & 石川 和 弘 \\
\hline 石 原 裕一 & 吉成伸夫 & 稲垣幸司 & 天埜克彦 \\
\hline & 山田 & 中川 種 昭* & 大島みどり* \\
\hline \multicolumn{4}{|c|}{ 北 村 秀 和* } \\
\hline & $\begin{array}{r}\text { 愛知学院大学歯学部 } \\
\text { （主任：野 } \\
\text { *東京歯科大学歯稆 } \\
\text { （主任 : 山田 } \\
\text { (平成 } 7 \text { 年 } 9\end{array}$ & $\begin{array}{l}\text { 科保存学第三講座 } \\
\text { 夋英教授) } \\
\text { 保存学第二講座 } \\
\text { 了教授) } \\
4 \text { 日受付) }\end{array}$ & \\
\hline
\end{tabular}

Studies on Clinical and Microbiological Evaluation of Minocycline Hydrochloride with a Local Drug Delivery System in the Acute Phase of Adult Periodontitis

Toshihide Noguchi, Akihiro Asai, Masanori Koide, Hideto Sakai, Yoshihiro Morita, Atsushi Mori, Tetsuo Takada, Motoyasu Murase, Nobuo Ueda, Takaho Kuroyanagi, Saeko Nishiyama, Kazuhiro Ishikawa, Yuichi Ishihara, Nobuo Yoshinari, Koji Inagaki, Katsuhiko Amano, Mitsuo Fukuda, Satoru Yamada*, Taneaki Nakagawa*, Midori Ohshima* and Hidekazu Kitamura*

Department of Periodontology, School of Dentistry, Aichi-Gakuin University 2-11, Suemori-dori, Chikusa-ku, Nagoya 464, Japan

(Chief : Prof. Toshihide Noguchi)

*Department of Periodontics, Tokyo Dental Collage

1-2-2, Masage, Mihama-ku, Chiba 261, Japan

(Chief : Prof. Satoru Yamada)

The effects of local drug delivery on the acute phase of periodontal disease were clinically and microbiologically studied using a resorbable minocycline-containing strip. The subjects of the study were 43 patients with no systemic disease and no history of antibiotic therapy within three months previously. All 43 patients complained of symptoms such as pain and tenderness from the acute phase area with occasional abscess formation. Minocycline containing strips were gently inserted till they reached the bottom of the pocket. Clinical changes were monitored on 0,3 and 7 day after insertion of strips, and microbiological changes on 0 and 7 day. Probing depth (PD), pain, tenderness, bleeding on probing (BOP), suppuration $(\mathrm{S})$ and the volume of gingival crevicular fluid (GCF) were 
recorded. Black Pigmented Gram-Negative Anaerobic Rods (BPNAR) and total anaerobic cultivable counts were made on non-selective blood agar.

Clinical symptoms such as pain, tenderness, BOP and $\mathrm{S}$ were significantly reduced on day 3 and 7 compared to the baseline. Significant reduction of $\mathrm{PD}$ and GCF were also found on 7 day. The preva- lence of BPNAR was significantly decreased on 7 day compared to the baseline.

These results of the present study indicate that the application of resorbable minocycline containing strips to pockets in the acute phase may be effective in improving the acute phase of periodontitis.

Key words: Acute phase of periodontitis, Local drug delivery in the periodontal pocket, Minocycline hydrochloride, Subgingival bacteria

要旨：本研究では, 歯周ポケット底部への到達性に優れ, 塩酸ミノサイクリンを含有し, 投与直後より徐々に 局所で溶解するストリップスタイプの薬剤の歯周炎の急性症状に対する局所投与の臨床的・細菌学的研究を行っ た。対象とした患者は，歯周病の急性症状を呈し，全身的疾患を有さず過去 3 ケ月以内に抗生物質の投与を受け ていない 43 名とした。43名全てに歯周炎局所由来の痛みを伴う発赤・腫脹または膿瘍形成が認められた。塩酸 ミノサイクリン含有のストリップスを歯周ポケット底部にまで挿入した。ストリップスを挿入後，0，3，7日後 の臨床症状の変化を観察し, 細菌学的変化を 0,7 日後に観察した。歯肉の発赤, 腫脹, 疼痛, プロービング深 さ (probing depth, PD), プロービング時出血 (bleeding on probing, BOP), 排膿 (suppuration, S), リン パ節所見および歯肉溝滲出液 (gingival crevicular fluid, GCF) 量の変化を記録した。黒色色素産生性グラム 陰性嫌気性桿菌（Black Pigmented Gram-Negative Anaerobic Rods, BPNAR) 数，生菌数は非選択性血液 平板培地で生育させて測定した。疼痛, 腫脹（口腔内）, BOP および S は, 薬剤投与後 3 日目および 7 日目で 投与開始時に比較して有意に減少していた。さらに，PDおよび GCF 量においても7日目において有意な減少 が観察された。投与前に優勢であった BPNAR の構成比率は投与開始直前と比較し，7日後では明らかに減少 していた。これらの結果から，歯周ポケット内への塩酸ミノサイクリン含有ストリップスの局所投与は，歯周炎 の急性症状の改善に有効であることが示唆された。

索引用語：歯周炎の急性期, 薬剤のポケット内局所投与, 塩酸ミノサイクリン, 歯周ポケット内細菌

\section{緒言}

歯周疾患は歯肉縁上プラークにより歯肉炎として発 症し，深い歯周ポケットを有する歯周炎へと進行する が, その進行には歯肉縁下プラークが深く関与してい ることが，これまで多数報告されている1 4)。歯周ポ ケット内細菌叢は, グラム陰性桿菌が比較的多くを占 め, Actinobacillus actinomycetemcomitans (A.a.), Porphyromonas gingivalis (P.g.), Eikenella corrodens (E.c.) などのいわゆる歯周病関連菌が検出され ており，これらの歯周病関連菌は，多くのビルレンス 因子5,6)を有することが報告されている。このため歯 周病の最大の局所因子である歯肉縁下プラーク中のこ れらの細菌をコントロールする目的で, 抗菌剤や抗生 物質などを歯周治療のひとつとして用いる方法が注目 され，全身的および局所的投与法に関する多くの報告 がなされている。さらに, 最近では薬剤に徐放性シス テムを賦与して歯周ポケット内細菌を効率よく抑制す るための種々の方法 (Local Drug Delivery Sys- tem, LDDS）が検討され，一部臨床応用されてい る $^{7 \sim 10)}$ 。

しかしながら，これらのLDDS のほとんどは歯周 病の慢性期, 急性期などの病態を, 特に考慮せずに投 与されてきた。

そこで, 本研究では歯周病の進行において，その組 織破壊が最も急速におこるとされている，急性期 (acute phase) と思われる時期に塩酸ミノサイクリン 含有のストリップスを歯周ポケット内に投与した場合 の細菌学的および臨床的効果を追及することを目的と した。

本研究に用いたストリップスは，すでに報告されて いるように ${ }^{11)}$, 歯周ポケット底部への到達性に優れ, 歯周ボケット内での楽効の持続性が高く, 臨床的にも 操作性が簡便な歯周病治療薬 (Strip type Drug for Periodontitis, SDP) である。また，ストリップス 中に含まれる塩酸ミノサイクリンは, 歯周病関連菌で あるP.g., Fusobacterium nucleatum (F.n.) 等に感 受性が高い薬剤である。

今回，われわれは $4 \mathrm{~mm}$ 以上の歯周ポケットを有 
し急性症状を呈する辺縁性歯周炎患者 43 名を対象に, SDP の歯周治療への応用の可能性を検索するために 医薬品の臨床試験の実施に関する基準 (Good Clinical Practice）を遵守した臨床研究を行ったので報告 する。

\section{材料と方法}

\section{1. 試験スケジュール}

$\mathrm{SDP}$ 投与は試験開始時のみとし, 臨床症状の観察 および微生物検査は図 1 の通りに行った。なおブラッ シングは被験者が通常行っている方法とした。

\section{2. 試験薬剤および投与方法}

今回使用した試験薬剤である SDP は，塩酸ミノサ イクリンの含有量が $20 \mathrm{mg} / \mathrm{g}$ （力価, $2 \%$ ）の, スト リップス状（幅 $1 \mathrm{~mm}$, 厚さ $0.3 \mathrm{~mm}$ で長さ $5 \mathrm{~mm}$ お よび $10 \mathrm{~mm}$ ）の挿入剤である。それぞれのサイズを プラスチック台紙に固定し，アルミ袋に入れ，常温で 保管した。SDP 投与方法は試験開始日に 1 回のみ投 与した (図 1)。

投与部位は急性症状を呈する歯を対象とした。急性 症状を呈する歯においては, 煩側, 舌側, 近心側およ び遠心側の 4 部位の中で, 歯周ポケットの深さが 4 $\mathrm{mm}$ 以上ある部位を対象に投与した。なお，急性症 状が隣接面に存在する場合には，両歯に投与した。

SDP のサイズの選定は，歯周ポケットの深さが約 $6 \mathrm{~mm}$ 以下の場合は長さ $5 \mathrm{~mm}$ サイズを, それ以上の 場合は $10 \mathrm{~mm}$ サイズを用いた。投与量（本数）は, 歯の煩側, 舌側, 近心側および遠心側の 4 部位で深さ $4 \mathrm{~mm}$ 以上の歯周ポケットで, 幅の広い（幅約 $3 \mathrm{~mm}$ 以上）ポケットには $2 \sim 3$ 本，狭いポケットには 1 本 を挿入した。SDPの挿入は, ゆっくりと行い, 歯周 ポケット底部にまで挿入した。

また被験者へ，投与直後の激しい洗口および飲食は 避けること, 試験期間中は被験者の用いている方法で ブラッシングを行うことを指示した。

併用療法は投与開始日にのみ必要に応じて, スケー

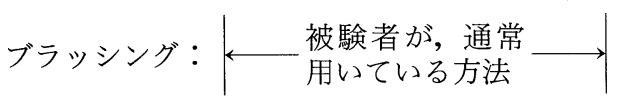

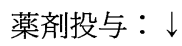

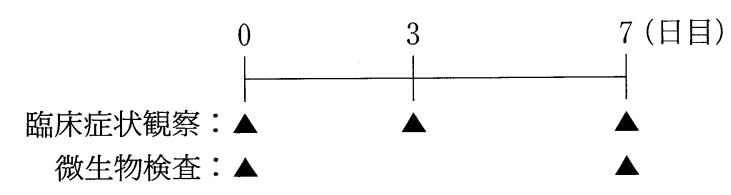

図 1 試験スケジュール
リング (歯肉縁上のみ), 切開，咬合調整を行った。 薬剤は試験薬剤以外は投与しなかった。

\section{3. 被験者および被験歯}

平成 6 年 9 月から平成 7 年 5 月までに愛知学院大学 歯学部附属病院歯周病科沶よび東京歯科大学千葉病院 保存科を受診し，全身的な疾患を有しない成人で，辺 縁性歯周炎の急性症状を呈し，かつその部位の歯周ポ ケットの深さが $4 \mathrm{~mm}$ 以上である外来患者 43 名を対 象とした。なお，急性症状とは，1）急性歯周膿瘍形 成，2）痛みを伴う発赤・腫脹の何れか 1 つ以上の条件 を満たすものとした。

また以下に該当する患者は対象から除外した。1) 75 歳以上の高齢者，2）3 力月以内に抗生物質の投与 を受けた患者，3）現在，薬剤を服用中の患者，4）塩 酸ミノサイクリンを含むテトラサイクリン系抗生物質 に対し過敏症の既往歴のある患者, および塩酸ミノサ イクリンの慎重投与に該当する患者，5）妊婦又は妊 娠している可能性のある患者，6）その他，担当医が 不適当と判断した患者。

また，SDP 投与開始前に，被験者に十分な説明を 行い，同意のもとに試験を実施した。

\section{4. 臨床診査方法 \\ 1) 観察部位}

予め 1 歯を指定し, 舌側・煩側, 近心・中央・遠心 の 6 部位のうち急性症状を呈した部位とした。

2）臨床症状の診査項目および判定基準

プロービング深さ (probing depth, PD), 歯肉の 発赤, 腫脹 (口腔内), 腫脹 (口腔外), 疼痛 (自発 痛), 疼痛 (咬合痛), 疼痛 (圧痛), 出血, 排膿, リ ンパ節所見および歯肉溝滲出液 (gingival crevicular fluid，GCF）量についてストリップスを挿入後，0， 3,7 日後に観察した（図 1)。さらにSDP 挿入時に, 挿入時の痛みを診査した。

臨床症状の診査項目の判定基準は次のように定め, 評価した。即ち，(1) 歯肉の発赤は「0：全く認められ ない」,「2：乳頭もしくは辺縁部に認められる」,「4： 付着歯肉まで及んで認められる」，(2) 腫脹（口腔内） は「0：全く認められない」,「2：乳頭もしくは辺縁部 に認められる」,「4：付着歯肉まで及んで認められ る」, (3) 腫脹 (口腔外) は「0：全く認められない」, $\lceil 1$ ：口腔外に腫脹の見られるもの」,「2：広範囲の腫 脹（たとえば下顎臼歯部では鶏卵大以上）」, (4) 疼痛 （自発痛）＜問診による判定＞は「0：なし」「「1：自 発痛のあるもの」,「2:激痛のあるもの」, (5) 疼痛 (咬合痛) <問診による判定 $>$ は「0：なし」「1：あ り」, (6) 疼痛（圧痛）＜問診による判定>は「0：指 で歯肉を押すとき痛みがないもの」「1：指で歯肉を 
押すとき痛みがあるもの」，(7) 出血は「0：プロービ ングで全く認められない」，「1：プロービングで認め られる」, 「2：自然に出血してくる」，(8) 排膿は「0： 指圧で全く認められない」,「1：指圧で認められる」, $\lceil 2$ ：自然に排膿してくる」，(9) リンパ節所見は「0： 腫脹なし, 又は疼痛のない腫脹」, 「1: 可動性で圧痛 をともなった腫脹」，「2：非可動性で圧痛をともなっ た腫脹」であり，(10) GCF 量は，エアーにて検査部を 乾燥後, ペリオペーパーを 5 秒間歯肉溝に挿入し, ペ リオトロン $6000^{\circledR}$ (Harco Electronics, Winnipeg, Canada）を用いて測定した。ただし，同一測定時の 初回の測定は棄却し, 第 2 回目の測定值を用いた。測 定時の血液混入の有無を調査票仁入した。また, 挿

表 1 重症度の判定基準

\begin{tabular}{|c|c|}
\hline 度 (P 1) & 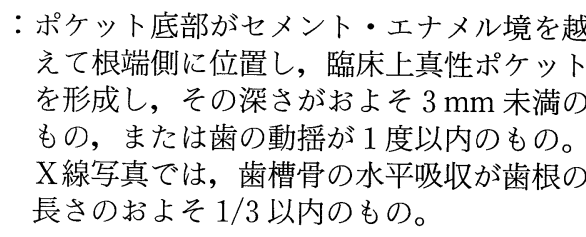 \\
\hline 中等度 (P 2) & $\begin{array}{l}\text { : 真性ポケットの深さが } 3 \sim 6 \mathrm{~mm} \text { 未満の範年 } \\
\text { 囲のもの, または歯の動摇が } 1 \sim 2 \text { 度以内の } \\
\text { もの, あるいは根分岐部病変が I または II } \\
\text { 度のもの。X線写真では, 歯槽骨の水平吸 } \\
\text { 収が歯根の長さの } 1 / 3 \sim 2 / 3 \text { の範囲のもの。 }\end{array}$ \\
\hline 高度 (P 3) & $\begin{array}{l}\text { : 真性ポケットの深さが } 6 \mathrm{~mm} \text { 以上のもの, } \\
\text { または歯の動摇が } 2 \sim 3 \text { 度以内のもの, } \\
\text { るいは根分岐部病変が II または III 度のも } \\
\text { の。X線写真では, 歯槽骨の水平吸収が歯 } \\
\text { 根の長さのおよそ } 2 / 3 \text { 以上のもの, あるい } \\
\text { は垂直性吸収が存在しているもの。 }\end{array}$ \\
\hline
\end{tabular}

入時の痛みく問診による判定 $>$ は $\Gamma 0$ : 全く痛くな い」,「1：少し痛い」, 「2: 我慢できるが痛い」, 「3： 我慢できないほど痛い」とした。

3) 重症度の判定

観察部位の歯周病重症度を，表 1 の判定基準をもと に判定した。

\section{5. 細菌検査方法}

1）検査部位および実施時期

検査部位は臨床症状観察部位と同部位とした。観察 開始日のストリップス挿入直前と，7 日後に試料を採 取した（図 1)。

\section{2) 試料採取}

滅菌綿球による簡易防湿下に，検查部位の歯肉縁上 プラークを滅菌綿球にて可及的に除去後, 滅菌ペー パーポイント（\# 45；Zipperer, Germany）3本を歯 周ポケット内に挿入し，30 秒間放置した。その後取 り出したペーパーポイントを $5 \mathrm{ml}$ の脱気リンゲル液 中に投入した。

3）培地への接種

脱気リンゲル液中の試料をボルテックスミキサーに より 1 分間分散後, 脱気リンゲル液を用い 10 倍連続 希釈を行い, 適度な希釈液 $0.1 \mathrm{~m} l$ ずつを非選択性の ブルセラ $\mathrm{HK}$ 血液寒天平板培地（極東, 東京: 以下 血液平板培地と略す）に接種した。

血液平板培地に塗布した希釈試料は, 株式会社 ビー・エム・エル（東京）に送付し， $35^{\circ} \mathrm{C}$ にて 5 日間 嫌気培養を行い, 生菌数および黒色色素産生性グラム 陰性嫌気性桿菌（Black Pigmented Gram-Negative Anaerobic Rods：BPNAR）数を算定した。

表 2 微生物学的判定基準

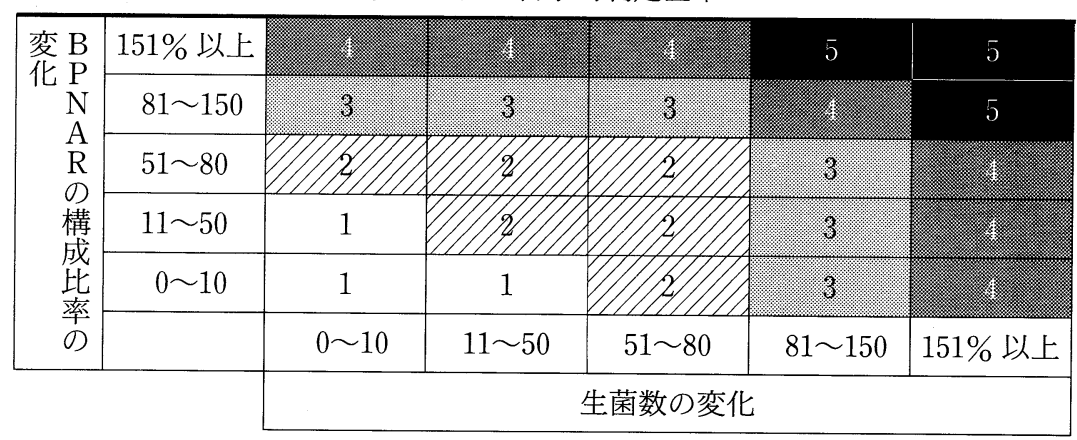

1. 著明改善 2. 中等度改善 3. 軽度改善 4. 不変 5 . 悪化

BPNAR の構成比率 $(\%)=(\mathrm{BPNAR}$ 数/生菌数 $) \times 100$

生菌数の変化および BPNAR の構成比率の変化は,

$$
\frac{\text { 薬㨈投与後 } 7 \text { 日目の値 }}{\text { 投与開始時の値 }} \times 100 \text { によって表した。 }
$$




\section{6. 判定基準}

微生物学的判定は表 2 の判定基準に従い，以下の 5 段階で評価した。即ち,「著明改善」,「中等度改善」, 「軽度改善」,「不変」,「悪化」のいずれかであった。 微生物学的判定の判定日は 7 日目とした。

また点数による効果判定は,「歯肉の発赤」,「腫脹 (口腔内) 」, 「腫脹 (口腔外) 」, 「疼痛 (自発痛)」, 「疼 痛 (咬合痛)」, 「疼痛 (圧痛)」,「リンパ節所見」, 「出 血」,「排膿」の 9 項目の総和から投与開始時に対する 判定日毎の評点比を求め, 切開の有無で層別されてい る判定基準を用い，切開無しの場合は 3 日目および 7 日目の, 切開有りの場合は 3 日目の評点比から, 以下 の 3 段階で評価した。即ち切開無し（表 3-1）は「著 効」(3日目 0.5 以下加 7 日目 0.3 以下), 「有効」 (3 日目で 0.7 未満かつ 7 日目で 0.7 未満，あるいは 7 日目で 0.5 末満)，「無効」(3日目で 0.7 以上かつ 7 日目で 0.5 以上，あるいは 7 日目 0.7 以上）の 3 段階 で評価した。次に切開有り（表 3-2）の場合は「著 効」(3日目で 0.3 以下), 「有効」(3日目で 0.3 を越 え, 0.7 末満),「無効」( 3 日目で 0.7 以上) の 3 段階 で評価した。

表 3-1 点数による効果判定基準 （切開を行わなかった場合）

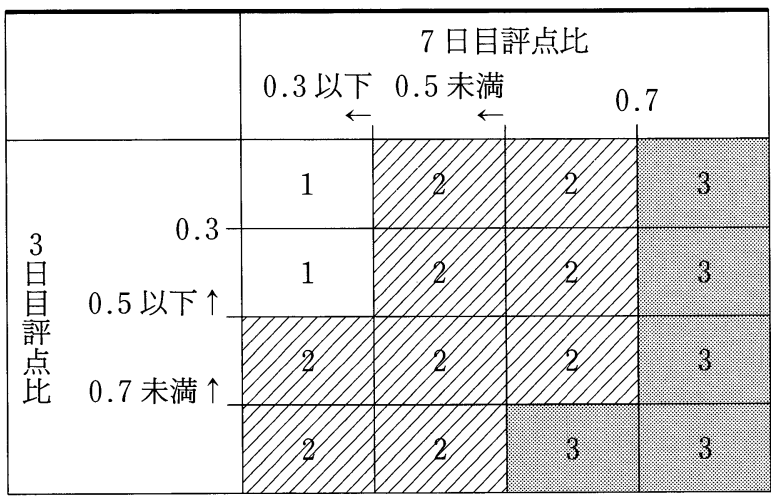

点数による効果判定

1. 著効： 3 日目 $\leqq 0.5$ かつ 7 日目 $\leqq 0.3$

2. 有効： 3 日目 $<0.7$ 加 7 日目 $<0.7$ あるいは 7 日目 $<0.5$

3. 無効： 3 日目 $\geqq 0.7$ かつ 7 日目 $\geqq 0.5$ あるいは 7 日目 $\geqq 0.7$
また, 微生物学的判定, 点数による効果判定, GCF 量の変化，PD の変化を参考に以下の 5 段階で 主治医による総合判定を行った。即ち，「著効」，「有 効」,「やや有効」,「無効」,「悪化」である。歯科局所 の安全度をみるため, 歯科局所における副作用を内容 と程度により以下の 4 段階で評価した。「安全性に問 題無し」,「ほぼ安全」,「安全性に問題有り」,「安全性 にかなり問題有り」の 4 段階である。「ほぼ安全」と は，例えば軽度の副作用は認められるが，治療処置を 必要とせず，投与継続には差支えないと考える程度の ものとし，「安全性に問題有り」とは，例えば副作用 により治療処置を行ったが継続投与可能な程度のもの とし，「安全性にかなり問題有り」とは，例えば強い 副作用により試験を中止し，あるいは中止すべき程度 のものである。

さらに歯科局所および全身的副作用を内容と程度に より次の 4 段階で評価し, 概括安全度とした。即ち, 「安全性に問題無し」,「ほぼ安全」,「安全性に問題有 り」,「安全性にかなり問題有り」である。安全性の具 体的な程度としては歯科局所の安全度の場合と同程度 を基準の内容とした。

表 4 の判定基準を目安に,「点数による効果判定」 と「安全度」とから, 有用度を「極めて有用」,「有 用」,「やや有用」，「有用でない」の 4 段階にて評価し た。

以上の研究終了後, すべての症例の取り扱いを検討 し, 集計解析対象症例を決定した。

表 4 有用度の判定基準

\begin{tabular}{|c|c|c|c|c|}
\hline \multirow{4}{*}{$\begin{array}{l}\text { 安 } \\
\text { 全 }\end{array}$} & $\begin{array}{l}\text { 4. 安全性にかな } \\
\text { り問題有り }\end{array}$ & 8 & ? & 8 \\
\hline & $\begin{array}{l}\text { 3. 安全性に問題 } \\
\text { 有り }\end{array}$ & 3 & 9 & 8 \\
\hline & 2. ほぼ安全 & 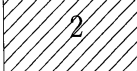 & 3 & 8 \\
\hline & $\begin{array}{l}\text { 1. 安全性に問題 } \\
\text { なし }\end{array}$ & 1 & & 8 \\
\hline & & 1. 著効 & 2. 有効 & 3. 無効 \\
\hline & & & 女による効 & 判定 \\
\hline
\end{tabular}

1 : 極めて有用 2 : 有用 3 : やや有用 4 : 有用でない

表 3-2 点数による効果判定基準（切開を行った場合）

\begin{tabular}{|c|c|c|c|}
\hline & \multicolumn{3}{|c|}{ 点数による判定 } \\
\hline & 著 効 & 有 効 & 無 効 \\
\hline 3 日目の評点比の範囲 & 評点比 $\leqq 0.3$ & $0.3<$ 評点比 $<0.7$ & $0.7 \leqq$ 評点比 \\
\hline
\end{tabular}




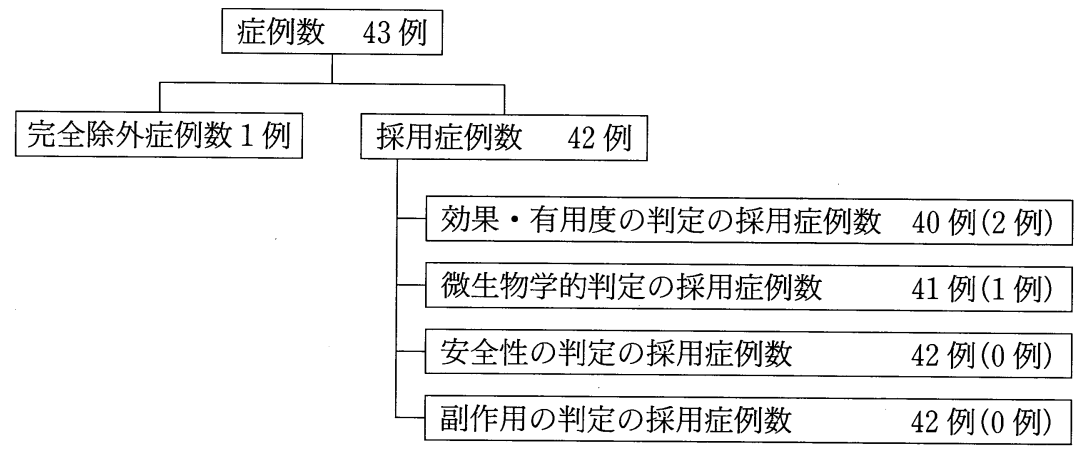

（ ）は除外症例数を示す。

図 2 集計・解析対象症例および除外症例の内訳

表 5 中止・脱落および規定違反等の取り扱い

\begin{tabular}{|c|c|c|c|c|c|}
\hline \multirow[b]{2}{*}{ 項 } & \multicolumn{5}{|c|}{ 採否 $(\bigcirc$ : 採用, $\times$ : 除外) } \\
\hline & $\begin{array}{r}\text { 効果の } \\
\text { 判定 }^{11}\end{array}$ & $\begin{array}{l}\text { 微生物学 } \\
\text { 的判定 }\end{array}$ & $\begin{array}{c}\text { 安全性の } \\
\text { 判定 }^{2)}\end{array}$ & $\begin{array}{l}\text { 副作用の } \\
\text { 判定 }^{3)}\end{array}$ & $\begin{array}{c}\text { 有用度の } \\
\text { 判定 }\end{array}$ \\
\hline \multicolumn{6}{|l|}{ [中止・脱落] } \\
\hline $\begin{array}{l}\text { 薬戍投与後, } 3 \text { 日目 } \\
\text { (第 } 1 \text { 回目判定) 前 }\end{array}$ & $x$ & $x$ & $\times$ & $x$ & $x$ \\
\hline \multicolumn{6}{|l|}{ [併用療法］ } \\
\hline 投与 3 日後の咬合調整 & $\bigcirc$ & 0 & $\bigcirc$ & $\bigcirc$ & 0 \\
\hline \multicolumn{6}{|l|}{ [合併症 $]$} \\
\hline 顔面神経麻痺 & $\bigcirc$ & $\bigcirc$ & $\bigcirc$ & $\bigcirc$ & $\bigcirc$ \\
\hline \multicolumn{6}{|l|}{ [期日違反] } \\
\hline $\begin{array}{l}3 \text { 日目の観察日のずれ } \\
\text { (土3 日以上 }\end{array}$ & $\times$ & O & $\bigcirc$ & $\bigcirc$ & $\times$ \\
\hline $\begin{array}{l}7 \text { 日目の観察日のずれ } \\
( \pm 2 \text { 日) }\end{array}$ & $\bigcirc$ & $\bigcirc$ & O & O & O \\
\hline $\begin{array}{l}7 \text { 日目の観察日のずれ } \\
( \pm 3 \text { 日以上 }\end{array}$ & $x$ & $x$ & $\bigcirc$ & $\bigcirc$ & $x$ \\
\hline
\end{tabular}

1）効果の判定 :「点数による効果判定」,「主治医の効果判定」

2）安全性の判定：「歯科局所の安全度」，「概括安全度」

3）副作用の判定：「歯科局所の副作用」，「全身的な副作用」

また歯周ポケット内微生物学的変化，臨床症状の変 化の解析は, 両側検定を採用し, 危険率 $5 \%$ 未満を有 意な差とした。なお，検定の手法はノンパラメトリッ クの Dunnett 型検定を用いた。

\section{結 果}

\section{1. 症例構成}

被験者の同意を取得し，試験薬剂の投与が行われた 症例は 43 名, 43 歯であった。そのうち, 完全除外症 例は 1 例で, 採用症例は 42 例であった。採用症例の
うち, 効果, 有用度の判定の採用例数は 40 例, 微生 物学的判定の採用例数は 41 例, 安全性の判定の採用 例数は 42 例, 副作用の判定の採用例数は 42 例であっ た（図 2)。

また，中止・脱落および規定違反の取り扱いについ ては表 5 に示したように行った。完全除外症例の 1 例 は中止・脱落した症例であり, 効果の判定, 微生物学 的判定, 安全性の判定, 副作用の判定, 有用度の判定 のすべてに除外となったため, 完全に除外した。中 止・脱落の理由は, 患者が来院しなかったためである。 採用された 42 例についての背景因子を表 6 に示し 
た。性別は男性 18 名, 女性 24 名で, 年齢は 29 歳以 下 0 名, 30 歳から 49 歳 19 名, 50 歳以上が 23 名で あった。重症度（表 1）は P 1 が 0 名, P 2 が 13 名, P 3 が 29 名であった。

\section{2. 臨床症状の経時的变化}

臨床症状の経時的変化のうち, GCF 量 $(\mu l)$ の変 化を血液が混入した症例を含ま好 16 例について示し たものが表 7 である。投与開始時 $0.81 \pm 0.10(\mu \mathrm{l}$ : 平均值士標準誤差）のものが， 7 日目には $0.37 \pm 0.11$ に減少した。検定を行ったところ，5\% 未満の危険率 で有意であった。また, それに伴い, PDも開始時 $8.00 \pm 0.31(\mathrm{~mm}$ : 平均值士標準誤差) であったもの が，3 日目には $6.73 \pm 0.31 ， 7$ 日目には $6.13 \pm 0.30$ に減少した。 3 日目, 7 日目の減少とも $1 \%$ 末満の危 険率で有意であった。

その他の臨床症状の結果は表 8-1, 表 8-2 に示し た。

「発赤」は，投与開始時に付着歯肉まで及んで認め られたもの（評点 4) が 29 名いたが， 3 日目には 5 名, 7 日目には 3 名に減少した。それ伴い, 発赤の 全く認められないもの（評点 0 ）が 7 日目には 10 名 になった。

「腫脹（口腔内）」は，投与開始時に付着歯肉まで及

表 6 背景因子

\begin{tabular}{cc|c}
\hline & & 症例数 \\
\hline 性別 & 男 & 18 \\
& 女 & 24 \\
年齢 & $\sim 29$ & 0 \\
& 30 49 & 19 \\
& 50 & 23 \\
重症度 & P 1 & 0 \\
& P 2 & 13 \\
& P 3 & 29 \\
\hline
\end{tabular}

んで認められる（評点 4）ものが 29 名いたが，3，7 日目には 4 名と減少した。それに伴い, 腫脹の全く認 められないもの（評点 0 ）が 7 日目には 11 名になっ た。

「疼痛（白発痛）」は，投与開始洔に激痛のむるもの (評点 2) が 40 名中 4 名, 自発痛のあるもの（評点 1 ) が 40 名中 14 名いたが，3 日目扔よび 7 日目にはすべ て疼痛のないもの（評点 0 ）になった。

「疼痛 (咬合痛)」は，投与開始時に疼痛のあるもの (評点 1) が 40 名中 22 名いたが， 3 日目には 6 名に減 り，7日目には 1 名となった。逆に疼痛のないもの （評点 $0 ）$ は 7 日目には 39 名になった。

「疼痛 (圧痛)」は，投与開始時に指で歯肉を押す時 痛みがあるもの（評点 1 ）が 40 名中 28 名いたが， 3 日目には 7 名に減り, 7 日目には 4 名となった。逆に 疼痛のないもの（評点 0$)$ は 7 日目には 36 名になっ た。

「出血」は，投与開始時に自然に出血してくるもの (評点 2) が 8 名いたが， 3 日目には 1 名， 7 日目には 0 名となった。逆にプロービングで出血の全く認めら れないもの（評点 0 ）が 7 日目には 26 名となった。

「排膿」は，投与開始時に自然に排膿してくるもの (評点 2) が 10 名いたが， 3 日目には 2 名， 7 日目に は 0 名となった。

以上「発赤」,「腫脹（口腔内）」, 「疼痛（自発痛）」, 「疼痛 (咬合痛) 」, 「疼痛 (圧痛) 」, 「出血」, 「排膿」 の項目はノンパラメトリックの Dunnett 型検定の結 果, 投与開始時と比べて 3 日目, 7 日目すべてにおい て危険率 $1 \%$ 末満の有意な変化を示していた。

「腫脹 (口腔外)」は，投与開始時および 3 日目で, 全く認められないもの（評点 0$)$ が 39 名で, 口腔外 に腫脹の認められるもの（評点 1) が1名であった が，7 日目には 40 名すべてが評点 0 となった。

「リンパ節所見」は，投与開始時に腫脹なし又は疼 痛のない腫脹（評点 0 ）が 30 名, 可動性で圧痛を 伴った腫脹（評点 1）が 10 名であったが， 7 日目には

表 7 臨床症状 (GCF, PD) の経時変化

\begin{tabular}{|c|c|c|c|}
\hline & 投与開始時 & 3 日目 & 7 日目 \\
\hline \multirow[t]{2}{*}{ GCF 量 $(\mu l)$} & $0.81 \pm 0.10^{2)}$ & $0.60 \pm 0.12$ & $0.37 \pm 0.11$ \\
\hline & & $* *$ & \\
\hline $\mathrm{PD}(\mathrm{mm})$ & $8.00 \pm 0.31^{2)}$ & $6.73 \pm 0.31$ & $6.13 \pm 0.30$ \\
\hline
\end{tabular}

1) 検定：ノンパラメトリックのDunett 型検定 $\quad *: \mathrm{p}<0.05 * *: \mathrm{p}<0.01$

2) 平均值土標準誤差を示す。 
表 8-1 臨床㾟状の経時的変化

\begin{tabular}{|c|c|c|c|c|}
\hline & & 投与開始時 & 3 日目 & 7 日目 \\
\hline \multirow[t]{4}{*}{ 発赤 } & 評点 & F & $-* *^{1)}$ & \\
\hline & 0 & $1^{2)}$ & 4 & 10 \\
\hline & 2 & 10 & 31 & 27 \\
\hline & 4 & 29 & 5 & 3 \\
\hline
\end{tabular}

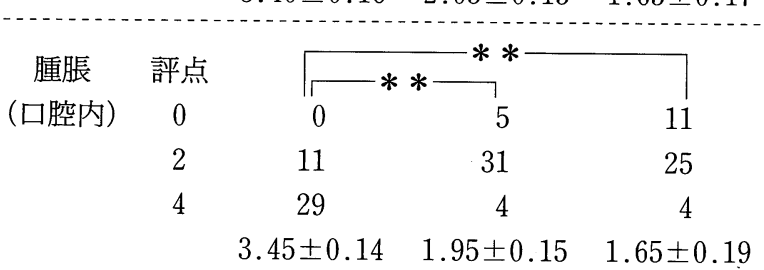

\begin{tabular}{|c|c|c|c|c|}
\hline \multirow{5}{*}{$\begin{array}{c}\text { 疼痛 } \\
\text { （自発痛） }\end{array}$} & 評点 & \multicolumn{2}{|c|}{ Гـ* $* * * *$} & \multirow[b]{2}{*}{40} \\
\hline & 0 & 22 & 40 & \\
\hline & 1 & 14 & 0 & 0 \\
\hline & \multirow[t]{2}{*}{2} & 4 & 0 & 0 \\
\hline & & $0.55 \pm 0.11$ & $0.00 \pm 0.00$ & $0.00 \pm 0.00$ \\
\hline 疼痛 & 評点 & \multicolumn{2}{|c|}{$* * * *$} & \multirow[b]{2}{*}{39} \\
\hline \multirow[t]{3}{*}{ （咬合痛） } & 0 & 18 & 34 & \\
\hline & 1 & 22 & 6 & 1 \\
\hline & & $0.55 \pm 0.08$ & $0.15 \pm 0.06$ & $0.03 \pm 0.03$ \\
\hline \multirow{4}{*}{$\begin{array}{l}\text { 疼痛 } \\
\text { (圧痛) }\end{array}$} & 評点 & \multicolumn{2}{|c|}{ Г一* } & \multirow[b]{2}{*}{36} \\
\hline & 0 & 12 & 33 & \\
\hline & \multirow[t]{2}{*}{1} & 28 & 7 & 4 \\
\hline & & $0.70 \pm 0.07$ & $0.18 \pm 0.06$ & $0.10 \pm 0.05$ \\
\hline \multirow[t]{5}{*}{ 出血 } & 評点 & \multicolumn{2}{|c|}{ ए $* * *$} & \multirow{2}{*}{26} \\
\hline & 0 & 2 & 15 & \\
\hline & 1 & 30 & 24 & 14 \\
\hline & 2 & 8 & 1 & 0 \\
\hline & & $1.15 \pm 0.08$ & $0.65 \pm 0.08$ & $0.35 \pm 0.08$ \\
\hline
\end{tabular}

1) 検定：ノンパラメトリックの Dunnett 型検定 $* *: \mathrm{p}<0.01$

2) 例数を示す。

3) 平均値士標準誤差を示す。

評点 0 が 38 名に増え, 評点 1 は 2 名に減少した。評 点 0 の被験者数の増加はノンパラメトリックのDunnett 型検定の結果，危険率 $5 \%$ 未満で有意であった。

\section{3. 点数による効果判定}

膿瘍形成および痛みを伴う発赤・腫脹の急性症状に 及汴すSDP の効果判定は歯性感染症に対する抗生物 質の効果判定基準に準じて行った（表 3-1，3-2）。表 9 に示したように膿瘍形成のみ認められた 7 例におい
表 8-2 臨床症状の経時的変化

\begin{tabular}{|c|c|c|c|c|}
\hline & & 投与開始時 & 3 日目 & 7 日目 \\
\hline \multirow[t]{5}{*}{ 排膿 } & 評点 & \multicolumn{2}{|c|}{$* * * * *$} & \\
\hline & 0 & $8^{2)}$ & 25 & 33 \\
\hline & 1 & 22 & 13 & 7 \\
\hline & 2 & 10 & 2 & 0 \\
\hline & & $1.05 \pm 0.11^{3}$ & $0.43 \pm 0.09$ & $0.18 \pm 0.06$ \\
\hline
\end{tabular}

\begin{tabular}{|c|c|c|c|c|}
\hline 腫脹 & 評点 & & & \\
\hline \multirow[t]{4}{*}{ (口腔外) } & 0 & 39 & 39 & 40 \\
\hline & 1 & 1 & 1 & 0 \\
\hline & 2 & 0 & 0 & 0 \\
\hline & & $0.03 \pm 0.03$ & $0.03 \pm 0.03$ & $0.00 \pm 0.00$ \\
\hline \multirow{5}{*}{$\begin{array}{l}\text { リンパ } \\
\text { 節所見 }\end{array}$} & 評点 & | & $-*$ & $\square$ \\
\hline & 0 & 30 & 33 & 38 \\
\hline & 1 & 10 & 7 & 2 \\
\hline & 2 & 0 & 0 & 0 \\
\hline & & $0.25 \pm 0.07$ & $0.18 \pm 0.06$ & $0.05 \pm 0.03$ \\
\hline
\end{tabular}

\footnotetext{
1) 検定：ノンパラメトリックの Dunnett 型検定$$
*: \mathrm{p}<0.05 * *: \mathrm{p}<0.01
$$

2) 例数を示す。

3) 平均値士標準誤差を示す。
}

ては，有効率（有効以上）が $85.7 \%$, 痛みを伴う発 赤・腫脹のみを呈したもの 7 例においては，有効率が $100 \%$, 膿瘍を形成し, 痛みを伴う発赤・腫脹のあるも の 26 例においては，有効率が $92.3 \%$ であった。全体 では，92.5\% の有効率が認められた。

\section{4. 主治医による判定効果}

主治医による判定効果は, 表 10 に示したような結 果になった。主たる急性症状として, 膿瘍形成のみ認 められた 7 例においては，有効率が $57.1 \%$ ，痛みを 伴う発赤・腫脹のみ認められた 7 例においては有効率 が $100.0 \%$, 膿瘍形成し, 痛みを伴う発赤・腫脹が認 められた 26 例においては, 有効率が $88.5 \%$ であっ た。全体では, $85.0 \%$ の有効率が認められた。

\section{5. 歯周ポケット内微生物の変化}

$\mathrm{SDP}$ 投与による歯周ポケット内微生物の変化を表 11 に示した。BPNAR 数は, 開始時 $3.31 \pm 0.33$ あっ たものが， 7 日目には $2.57 \pm 0.32 に$ 減少した。生菌 数も開始時 $4.60 \pm 0.21$ であったものが， 7 日目には $4.35 \pm 0.18$ に減少した。また BPNAR の構成比率は 開始時 $29.09 \pm 4.81$ であったものが，7日目には $13.55 \pm 2.81$ に減少していた。これは, 危険率 1\%末 満で有意であった。

SDP の微生物学的評価を行った結果を表 12 に示し 
表 9 点数による効果判定

\begin{tabular}{ccccc}
\hline \multirow{2}{*}{ 症状 } & \multicolumn{4}{c}{ 効 果 判 定 } \\
\cline { 2 - 5 } & 著効 & 有効 & 無効 & 合計 \\
\hline 脹瘍形成のみ & $1(14.3)$ & $5(85.7)$ & 1 & 7 \\
痛みを伴う発赤・腫脹のみ & $1(14.3)$ & $6(100.0)$ & 0 & 7 \\
膿瘍形成十痛みを伴う発赤・腫脹 & $5(19.2)$ & $19(92.3)$ & 2 & 26 \\
\hline 合計 & $7(17.5)$ & $30(92.5)$ & 3 & 40 \\
\hline
\end{tabular}

（ ）内は，累積\%を示す。

表 10 主治医による効果判定

\begin{tabular}{crrrrrr}
\hline \multirow{2}{*}{ 症状 } & \multicolumn{7}{c}{ 効 果 判 } & 定 \\
\cline { 2 - 7 } & 著効 & 有効 & やや有効 & 無効 & 悪化 & 合計 \\
\hline 膿瘍形成のみ & $1(14.3)$ & $3(57.1)$ & $3(100.0)$ & 0 & 0 & 7 \\
痛みを伴う発赤・腫脹のみ & $3(42.9)$ & $4(100.0)$ & $0(100.0)$ & 0 & 0 & 7 \\
膿瘍形成十痛みを伴う発赤・腫脹 & $7(26.9)$ & $16(88.5)$ & $1(92.3)$ & 2 & 0 & 26 \\
\hline 合計 & $11(27.5)$ & $23(85.0)$ & $4(95.0)$ & 2 & 0 & 40 \\
\hline
\end{tabular}

（ ）内は，累積\%を示す。

表 11 ポケット内微生物の変化

\begin{tabular}{c|cc|c}
\hline 項目 & 投与開始日 & 投与 7 日後 & 検定 $^{3)}$ \\
\hline BPNAR 数の変化 & $3.31 \pm 0.33^{1)}$ & $2.57 \pm 0.32^{1)}$ & N.S. ${ }^{4)}$ \\
生菌数の変化 & $4.60 \pm 0.21^{1)}$ & $4.35 \pm 0.18^{1)}$ & N.S. \\
BPNAR の構成比率の変化 & $29.09 \pm 4.81^{2)}$ & $13.55 \pm 2.81^{2)}$ & $\mathrm{p}<0.01$ \\
\hline
\end{tabular}

1) $\log (\mathrm{CFU})$ の平均値士標準誤差（但し， $\log 0$ は 0 とする）

2) 構成比率 $(\%)$ の平均值士標準誤差（但し，0/0 は 0 とする)

3) 検定：Dunnett 検定により，各項目の投与開始時と投与終了時とを比較。

4) N.S. : 有意差なし

表 12 微生物学的評価の判定

\begin{tabular}{l|ccccc|c}
\hline & 著明改善 & 中等度改善 & 軽度改善 & 不変 & 悪化 & 合計 \\
\hline 微生物学的 & 13 & 3 & 6 & 14 & 5 & 41 \\
評価 & $(31.7 \%)$ & $(39.0 \%)$ & $(53.7 \%)$ & & & \\
\hline
\end{tabular}

（ ）内は，累積\%を示す。

表 13 安全度

\begin{tabular}{c|cccc|c}
\hline 項目 & $\begin{array}{c}\text { 安全性に } \\
\text { 問題無し }\end{array}$ & ほぼ安全 & $\begin{array}{c}\text { 安全性に } \\
\text { 問題有り }\end{array}$ & $\begin{array}{c}\text { 安全性にかな } \\
\text { り問題有り }\end{array}$ & 合計 \\
\hline 歯科局所の安全度 & $42(100 \%)$ & 0 & 0 & 0 & 42 \\
概括安全度 & $42(100 \%)$ & 0 & 0 & 0 & 42 \\
\hline
\end{tabular}

（ ）内は，累積\%を示す。 
た。「著明改善」が 41 症例中， 13 例 $(31.7 \%)$,「中等 度改善」が 3 例 $(7.3 \%)$,「軽度改善」が 6 例 $(14.6 \%)$, 「不変」が 14 例 $(34.2 \%)$,「悪化」が 5 例 (12.2\%) であった。

\section{6. 安全度}

歯科局所の安全度, 概括安全度についての結果を表 13 に示した。

42 症例について, 両安全度とも「安全性に問題無 し」と判定された。

\section{7. 副作用}

副作用についての結果を表 14 に示した。

42 症例すべてについて, 局所の副作用, 全身的な 副作用とも「副作用無し」の結果を得た。

\section{8. 挿入時の痛み}

挿入時の痛みについての結果を表 15 に示した。 挿入時の痛みは，投与開始時において，「全く痛く ない」としたものが 19 例 $(45.2 \%)$ ，「少し痛い」 17 例 $(40.5 \%)$ ，「我慢できるが痛い」5例 (11.9\%), 「我慢できないほど痛い」1例 $(2.4 \%)$ であった。

\section{9. 有用度}

有用度についての結果を表 16 に示した。

主たる急性症状として, 膿瘍形成のみ認められた 7 例においては, 有用率（有用以上）が $85.7 \%$, 痛み を伴う発赤・腫脹のみ認められた 7 例においては有用 率が $100.0 \%$, 膿瘍形成し, 痛みを伴う発赤・腫脹が

\begin{tabular}{c|cc}
\multicolumn{3}{c}{ 表 14 副作用 } \\
\hline 項目 & 副作用無し & 副作用有り \\
\hline 歯科局所の副作用 & 42 人 & 0 人 \\
全身的な副作用 & 42 人 & 0 人 \\
\hline
\end{tabular}

認められた 26 例においては, 有用率が $92.3 \%$ であっ た。全体では，92.5\%の有用率が認められた。

\section{考察}

歯周病の発症と進行に歯肉縁下プラーク細菌が深く 関与していることが多くの研究者によって明らかにさ れ, 歯周病の治療における歯肉縁下のプラークコント ロールが重要となってきている。

従来, 歯肉縁下のプラークコントロールは機械的方 法が主体であった。しかし，近年，LDDSを応用し た抗菌剤や抗生物質のポケット内局所投与法が開発さ れ, 歯周病の治療において良好な結果が得られてい る。しかし, 現実問題として, 日常の臨床における抗 生物質の使用は，急性症状の緩和を目的とした数日間 にわたる全身的な経口投与が一般的であり, 常に副作 用や耐性菌の発現の危険性を伴っている ${ }^{12)}$ 。そこで, 本研究では, 全身投与に比較して投与量が少なく, 直 接ポケット内へ薬剤を投与することを目的として開発 した，塩酸ミノサイクリン含有のストリップスタイプ 製剤であるSDPを用いて，急性症状に対する効果お よびその有用性について検討した。なお，本研究にお いて顔面神経麻痺を合併している被験者が 1 名存在し ていたが, 軽度であったため本研究に影響を及ぼさな いと判断し，採用とした。

本研究で用いた SDP は, ストリップス 1 本（幅 1 $\mathrm{mm}$, 厚さ $0.3 \mathrm{~mm}$, 長さ $10 \mathrm{~mm}$ のの）あたり, 約 $0.07 \mathrm{mg}$ 力価の塩酸ミノサイクリンが含有されて いる。これをポケット内に 1 本から数本挿入するが, 経口投与時には 100〜 200 mg/日必要とされている全 身投与療法に比較して極めて少ない量である。本研究

表 15 捕人時の痛み

\begin{tabular}{c|cccc}
\hline 投与時期 & 全く痛くない & 少し痛い & $\begin{array}{l}\text { 我慢できる } \\
\text { が痛い }\end{array}$ & $\begin{array}{l}\text { 我慢できない } \\
\text { ぼ痛い }\end{array}$ \\
\hline 投与開始時 & $19(45: 2 \%)$ & $17(85.7 \%)$ & $5(97.6 \%)$ & 1 \\
\hline
\end{tabular}

（ ）内は，累積\%を示す。

表 16 有用度の判定

\begin{tabular}{cccccrc}
\hline \multirow{2}{*}{ 症状 } & \multicolumn{5}{c}{ 判 } & 定 \\
\cline { 2 - 6 } & 極めて有用 & 有用 & やや有用 & 有用でない & 合計 \\
\hline 膿瘍形成のみ & $1(14.3)$ & $5(85.7)$ & $0(85.7)$ & 1 & 7 \\
痛みを伴う発赤・腫脹のみ & $1(14.3)$ & $6(100.0)$ & $0(100.0)$ & 0 & 7 \\
膿瘍形成十痛みを伴う発赤・腫脹 & $5(19.2)$ & $19(92.3)$ & $0(92.3)$ & 2 & 26 \\
\hline 合計 & $7(17.5)$ & $30(92.5)$ & $0(92.5)$ & 3 & 40 \\
\hline
\end{tabular}

（ ）内は，累積\%を示す。 
では，SDP 投与は 1 回のみで，投与時，3 日目， 7 日 目に臨床症状の観察を行うとともに，投与時と 7 日目 に微生物検査を行った。

効果判定を見ると，点数による効果判定では 92.5\%，主治医による効果判定ではやや有効を含めて 95.0\%に効果が認められた。また, 症状別に経時的 変化をみると, 発赤, 腫脹 (口腔内), 疼痛 (自発痛, 咬合痛, 圧痛), 出血, 排膿および PD は, SDP 投与 3 日目に有意に減少し, 早期に臨床的効果が現れてい ることがわかる。特に，患者にとって最も気になると 思われる自発痛は，3 日目には $100 \%$ 消失している。 また， 7 日目にはリンパ節所見と GCF 量も有意に減 少し, 口腔外の腫脹も消失している。したがって, 臨 床的に極めて有効であることが強く示唆された。ま た，SDP使用に際しての安全度に関しては，歯科局 所の安全度および概括安全度の両者とも「安全性に問 題無し」が 100\%であり, 副作用に関しても,「副作 用無し」が $100 \%$ となっており，安全性にも優れてい ると思われる。また，SDP 挿入時の痛みに関しては， $\mathrm{SDP}$ 挿入時の痛みが「全く痛くない」ものが $45.2 \%$ ，「少し痛い」ものが $40.5 \%$ ，合わせて $85.7 \%$ が無痛もしくは軽度の痛みであることから, 急性症状 を呈している部位への SDP 投与も特に問題は無いも のと思われる。

点数による効果判定と安全度を総合的に判定した有 用度をみると，92.5\% が有用であるとの判定となり， 急性症状に対して有用であることが確認された。

歯周ポケット内微生物の変化についても検討を加え た。急性症状が認められる歯周ポケットの大部分は, 排膿もしくは膿汁の貯留による腫脹が観察される。奥 田 ${ }^{13)}$ は, 排膿が認められた歯周ポケットと認められな かった歯周ポケットの歯肉縁下プラーク細菌叢を比較 検討した結果，総菌数では差は認められなかったもの の, Spirochetes と Black-pigmented Bacteroides に 関してはそれぞれの菌の構成比率が排膿が認められた 歯周ポケットにおいて有意に高く, とくに Black -pigmented Bacteroides の構成比率は $23.9 \%$ と最も 高かったと報告している。そこで, 本研究では, BPNAR 数が生菌数に占める割合についても検討を 加えた。その結果, SDP投与開始時は, 平均 $29.09 \%$ と奥田の報告とほぼ同様であったが，7日目 には平均 $13.55 \%$ に減少し, BPNARの構成比率の 有意な減少が認められた。したがって, SDP は微生 物学的見地からも急性症状に対して有効であると推察 された。

なお, 成人性歯周炎急性症状に対する LDDS 投与

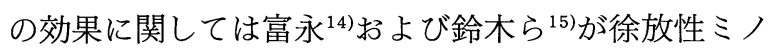

サイクリン製剤（Periocline ${ }^{\circledR} ，$ サスター，大阪， 以下 PER と略す）を用いて報告している。その結果 を本研究と比較してみると, 富永は, 臨床症状では $\mathrm{PD}$ が約 $2 \mathrm{~mm}$ 減少したと報告しており，本研究結果 とほぼ同様の值を示し, 発赤, 腫脹, 疼痛および排膿 などの消退も本研究と同様の結果であった。また，鈴 木らは, 腫脹および疼痛は PER 投与 3 日後という早 期に改善が見られたが，出血に関しても改善が認めら れたと報告しており，本研究においても同様な結果が 認められた。本研究ではさらに炎症の程度を客観的に 知る 1 つの手段である GCF 量の変化も観察したが, SDP 投与 7 日後において有意な減少が認められた。

また, 歯周ポケット内細菌のうち, 進行性歯周炎で 最も多く検出される BPNAR の構成比率の減少を比 較してみると, 富永 ${ }^{14)}$ は薬剤投与前 $23.6 \%$ から投与 後 $7.1 \%$ に変化（ただし生菌数に対するP.g. の割合） したと報告しており，本研究では $29.09 \%$ から $13.55 \%$ に変化し, 共に統計学的に有意な減少を示し ていた。また, 微生物学的評価において悪化と判定さ れたものが 5 名認められ，ほとんどが SDP 投与時に BPNAR の構成比率の低かった症例であった。これ は, 点数による効果判定においては 5 名すべてが有効 と判定されていることから, 今回の試験において両隣 在歯への SDP 投与を行わなかったことが原因の 1 つ ではないかと推察される。

以上，今回使用した SDP は，通常の塩酸ミノサイ クリン経口投与に比較して極めて少ない量にもかかわ らず，短期間で臨床症状の改善および BPNAR の構 成比率の減少が認められ, 臨床的に有効であることが 示唆された。すなわち, 副作用や而性菌の発現の危険 性を考慮した場合, 少量の抗生物質投与で効果が認め られる本法は, 急性症状に対する処置として安心して 用いられる方法であると思われる。

\section{文献}

1) Haffajee, A.D., Socransky, S.S., Ebersole, J.L. and Smith, D.J. : Clinical, microbiological and immunological features associated with the treatment of active periodontosis lesions. J. Clin. Periodontol., $11: 600-618,1984$.

2) Moore, W.E.C., Holdeman, L.V., Cato, E.P., Good, I.J., Smith, E.P., Ranney, R.R. and Palcanis, K. G. : Variation in periodontal floras. Infect. Immun., $46:$ 720-726, 1984.

3) Socransky, S.S. : Microbiology of periodontal disease-present status and future considerations. J. Periodontol., 48 : 497-504, 1977. 
4) Tanner, A.C.R., Haffer, C., Bratthall, G.T., Visconti, R.A. and Socransky, S.S. : A study of the bacteria associated with advancing periodontitis in man. J. Clin. Periodontol., 6:278-307, 1979.

5) Van Steenbergen, T.J.M., Kastelein, P., Touw, J. J.A. and De Graaff, J. : Virulence of black-pigmented Bacteroides strains from periodontal pockets and other sites in experimentally induced skin lesions in mice. J. Periodont. Res., $17: 41-49$, 1982.

6) Neiders, M.E., Chen, P.B., Suido, H., Reynolds, H. S., Zambon, J.J., Shlossman, M. and Genco, R.J. : Heterogeneity of virulence among strains of Bacteroides gingivalis. J. Periodont. Res., 24: 192 $-198,1989$.

7）野口俊英, 福田光男, 北村 滋, 小林 誠, 梅田 誠, 石川烈, 鈴木嘉樹：歯周ポケット内への薬 率の局所投与が歯肉縁下細菌叢および臨床症状に及 ぼす影響. 日歯周誌, 28：737-743, 1986.

8）上田雅俊，山岡 昭，前田勝正，青野正男，鈴木基 之, 長谷川紘司, 宮田裕之, 鴨井久一, 楠 公仁, 池田克巳 : 歯周炎に対する LS-007 の有効性と有用 性に関する臨床的ならびに細菌学的検討. 日歯周 誌, $30 ： 223-235,1988$.

9) Goodson, J.M., Cugini, M.A., Kent, R.L., Armitage, G.C., Cobb, C.M., Fine, D., Fritz, M.E., Green, E., Imoberdorf, M.J., Killoy, W.J., Mendieta, C., Niederman, R., Offenbacher, S., Tag- gart, E.J. and Tonetti, M. : Multicenter evaluation of tetracycline fiber therapy. II. Clinical response. J. Periodont. Res., 26 : 371-379, 1991

10) Michalowicz, B.S., Pihlstrom, B.L., Drisko, C.L., Cobb, C.M., Killoy, W.J., Caton, J.G., Lowenguth, R.A., Quinones, C., Encarnacion, M., Knowles, M. and Goodson, J.M. : Evaluation of periodontal treatments using controlled-release tetracycline fibers: Maintenance response. J. Periodontol., $66: 708-715,1995$.

11）野口俊英，福田光男，立花智子，鈴木知香子，北村 滋，宮川みほ，小林 誠，泉澤勝憲，木下四郎，鈴 木嘉樹, 井倉 宏: 歯肉縁下プラークをコントロー ルするための新しい試み. 日歯周誌, $25: 554-561$, 1983.

12) Lacroix, J.M., Lennon, J., Nango, S., Rivera, M. and Walker, C.B.: Detection of the tetracycline resistance gene Tet $(\mathrm{M})$ in periodontal pockets. J. Dent. Res., 72 : 157, abstr. 425, 1993.

13）奥田一博：排膿と歯周ポケット内細菌叢との関連に ついて. 日歯周誌, $27: 757-770,1985$.

14）冨永由美子：成人性歯周炎急性症状に関する細菌学 的研究. 日歯周誌, $36: 1-17,1994$.

15）鈴木邦治, 田中宏司, 藤川謙次, 伊藤公一, 村井正 大，熊谷 崇：歯周炎急性症状に対するぺリオクリ ン歯科用軟膏の臨床的効果の検討. 歯界展望, 78 ： 1351-1360, 1991.

連絡先：

愛知学院大学歯学部歯科保存学第三講座

干 464 名古屋市千種区末盛通 2-11 